OSOBA | SAMOTNOŚĆ. MIĘDZY CODZIENNOŚCIA A MISTYKA

Filozofia ChrześcijańsKa • Tom 12, Poznań 2015

Uniwersytet im. Adama Mickiewicza w Poznaniu - Wydziaz Teologiczny

doi: $10.14746 /$ fc.2015.12.10

NATALIA ROSOSIŃSKA-KOZUB

\title{
Samotnik w Międzyludzkim', czyli o życiu i twórczości Emila Ciorana
}

\section{A Loner in the Interpersonal or about Emil Cioran's Life and Works}

Wszelakie rozważania o samotności należałoby opatrzyć klauzulą subtelnego ich traktowania, jako że materia to zdecydowanie delikatna, w związku z czym nietrudno o szybkie jej nadużycie, spłycenie, zbanalizowanie z jednej strony, $\mathrm{z}$ drugiej natomiast - istnieje również niebezpieczeństwo pompatycznego, przesadnego lub patetycznego do niej podejścia. Jak zatem przybliżyć się do zagadnienia samotności, któremu niechybnie na przeciwległym biegunie odwzorowuje się jedno z jego przeciwieństw - wspólnotowość? Jak właściwie rozeznać tę dialektykę, adekwatnie ją rozpoznać i poddać rzetelnej oraz wyważonej analizie? Ośmieliwszy się założyć, że odpowiedni rekonesans obu zagadnień możliwie najlepiej zobrazować poprzez odniesienie do konkretnego przykładu, postanowiłam podjąć rzeczoną próbę zarysowania tytułowej dialektyki na przykładzie twórczości rumuńskiego filozofa XX wieku - postaci Emila Ciorana. Wybór ten jest nieprzypadkowy. Po pierwsze dlatego, że rumuński myśliciel zasłynął z kontrowersyjnej ciagle w kręgach kultury europejskiej idei samobójstwa, a zagadnienie natury suicydalnej pozostaje bliskie wszelkim refleksjom nad samotnością. Po drugie dlatego, iż pomimo tejże idei właśnie zdecydowanie nie jest bohaterem dyskursu o samotności, a warto by pokazać, że doskonale się w niego wpisuje, a jego twórczość jest bez wątpienia, choć niesystematyczna, to systemowa, bo

${ }^{1}$ Terminem „Międzyludzkie” posługuję się w nawiązaniu do jego sformułowania i użycia przez W. Gombrowicza, nie roszcząc sobie praw do stworzenia nowej kategorii, którą przykładać będę w niniejszej pracy do wymiaru samotności, jaki rysuje się na kartach dzieł rumuńskiego myśliciela i aforysty, Emila Ciorana. Terminu tego będę używać jako antynomii do fenomenu samotności oraz jako synonimu fenomenu wspólnotowości. Przy tym zastrzegam, że jego użycie nie wiąże się z żadną analizą twórczości popełnionej przez znakomitego, polskiego literata, wyżej wymienionego W. Gombrowicza, jako że cel niniejszego artykułu jest zgoła inny. 
obejmuje całość zagadnień filozoficznych - od Boga, przez świat, człowieka i przynależne mu dziedziny ${ }^{2}$. Wreszcie, po trzecie, postać Emila Ciorana wymaga zwłaszcza w intelektualnej rzeczywistości polskiej ciagle jeszcze popularyzacji i wyjaśnień, by ukrócić wszelkie opierające się na nierzetelnych i masowych źródłach komentarze redukujące jego talent jedynie do krótkiej przygody z partią faszystowską. Zasadniczym celem niniejszego tekstu jest zatem przybliżenie zarówno osoby Emila Ciorana, jak i licznych dzieł stanowiących o jego bogatym intelektualnym dorobku w kontekście zarysowania analogii, jaka występuje równolegle pomiędzy poniższymi członami: życie - twórczość oraz samotność wspólnotowość. W toku swojego artykułu podejmę próbę ukazania dialektyki tytułowych fenomenów, stanowiącej bezsprzeczną charakterystykę biografii i twórczości Ciorana.

Mówiąc o dialektyce samotności i wspólnotowości, należałoby raczej nie koncentrować się na ich wzajemnej antynomiczności, lecz przenieść punkt ciężkości albo na samotność, albo na wspólnotowość, tudzież przeprowadzić obserwacje z centrum każdego z tych fenomenów. Gombrowiczowskie „Międzyludzkie" to funkcja relacji, które zachodzą między ludźmi właśnie, współtworząc ich osobowości, jednakże nie należy zapominać, że człowiek pozostający w relacjach $\mathrm{z}$ innymi jednocześnie pozostaje sam sobie we własnym wnętrzu i w tym najintymniejszym miejscu sam z sobą podejmuje zmagania. Pozostając w przekonaniu, że fenomen samotności wykazuje paradoksalnie dużo większą zaborczość niż fenomen wspólnotowości, skoncentruję swoją uwagę przede wszystkim na samotności, analizując ją na modelu osoby i twórczości Emila Ciorana.

Emil Cioran jest postacią bardzo cenioną, jego twórczość zaś doczekała się licznych komentarzy i wielokrotnych cytowań, choć należy zaznaczyć, że przede wszystkim w kręgu kulturowym Rumunii. Tam oto, w swej ojczyźnie, którą niejednokrotnie wyśmiewał i w którą rzucał literackimi bluźnierstwami, którą pogardzał, obrażał, do której swój specyficznie patriotyczny stosunek wyraził w dziele dotąd nieprzetlumaczonym na język polski (rumuński tytuł to Schimbarea la față a României, opublikowana w Bukareszcie w 1936), Emil Cioran zdobył ugruntowaną pozycję jako intelektualista, stając w szeregu z największymi umysłami, tj. Mirceą Eliadem, Eugene Ionesco, Constantinem Noiką. Jest on także regularnie brany pod skrzydła obronne przed wszelakimi atakami zagranicznych biografów oraz interpretatorów jego dzieł. Jego rola nie została jednak umniejszona w drugiej, zaadaptowanej przez niego ojczyźnie - Francji, w której

\footnotetext{
${ }^{2}$ Warto zauważyć, że Cioran występował przeciw filozofii systemowej, dogmatycznej, kompletnej. Jego twórczość to furia fragmentu. Używając określenia „systemowa” w odniesieniu do jego filozoficznej myśli, rozumiem to jako całościowy ogląd filozoficzny, w ramach którego pisarz podejmuje całą rozpiętość zagadnień, nie skupiając się na przykład wyłącznie na epistemologii. Choć pewne kwestie stanowią lejtmotyw jego dorobku intelektualnego, to odnaleźć w nim można wszelki wymiar ludzkiej egzystencji.
} 
spędził najdłuższą część swojego życia, a biorąc pod uwagę swój okres twórczy - największą. Jednakże tu już pojawiają się głosy krytyki wymierzone nie tyle w jego talent, który raczej nie został zakwestionowany, ile w „czystość” jego biografii. Sylwetka Ciorana w Polsce rysuje się znacznie ubożej, bo albo jest tylko i wyłącznie kojarzony z ideą samobójstwa, która notabene nie cieszy się poparciem większości polskich elit intelektualnych, albo zamiast filozoficznego i literackiego koncentrowania na jego dorobku intelektualnym dochodzi do bardzo zdawkowego prześwietlania jego życia i wyciagania sensacyjnych wątków ogołoconych z potrzebnego kontekstu. Sytuacja ta ulega jednak zmianie, która polega m.in. na coraz częstszych odniesieniach do jego myśli twórczej, czy też na poruszaniu wątków jego pisarstwa dotychczas niewyeksponowanych. Inspiracją do niniejszego artykułu, winna jestem czytelnikowi szczerość, była wspomniana kontrowersyjna idea samobójstwa jako zagadnienie najściślej i najwyraźniej połączone z refleksją nad samotnością. Jednakże jest to jedynie zalążek dalszych rozważań, w których można popisać się bogatym materiałem dowodowym na to, w jaki sposób Emil Cioran był uwikłany w samotność, w jak pokaźnym stopniu wypełniała ona stronice jego dzieł i jak przy tym jednocześnie zachowywał pozory szalenie uspołecznionego intelektualisty, który nieprzerwanie dąży do wzbogacania swych relacji z ludźmi. Fenomen samotności pojawia się w aforystycznych uniesieniach i degradacjach Ciorana nie rzadziej aniżeli idea samobójstwa, opiewanie uroków śmierci, wywoływanie Boga, afirmacja cierpienia czy szczera tęsknota za nicością. Jego miejsce na kartach Cioranowskich literackich dzieł choć nie jest honorowe, bo nie stanowi lejtmotywu jego myśli, to zdecydowanie należy do drugoplanowych, pełniąc funkcję tła, który ma charakter eksplikatywny względem reszty podejmowanych zagadnień. Samotność, którą czytelnik odnajdzie, zagłębiając się w Cioranowskie „wynurzenia”, to samotność, która nie ma w sobie nic z nachalności, samotność, która jest ekskluzywna i wysublimowana. Cioranowska samotność niejednokrotnie w sposób przewrotny wchodzi w relację ze wspólnotowością, choć gra ta nie jest bezpośrednio czytelnikowi dana, odbywa się w sposób zawoalowany i wymaga dokładnego rozpoznania życia i twórczości rumuńskiego filozofa, ażeby zostać zauważoną. Czytając Ciorana, można natknąć się na fragmenty, w których obraża człowieka jako gatunek, gardzi ludźmi jako pewną zbiorowością pozbawioną cnoty mądrości, wyraża swoją nienawiść do jakiegokolwiek tłumu, życząc mu najchętniej eksterminacji. „Wierzę w ocalenie ludzkości, w przyszłość cyjanku [...]”3 pisze rumuński filozof w Sylogizmach goryczy, dziele opublikowanym w okresie dojrzałości autora. Kilka stronic dalej w tym samym rozdziale odnajdujemy zwierzenie zgoła przeciwne: „Ze zgrozą patrzę, jak słabnie moja nienawiść do ludzi, rozluźnia się ostat-

\footnotetext{
${ }^{3}$ E. Cioran, U źródet pustki, w: Sylogizmy goryczy, thum. I. Kania, Warszawa 2009, s. 161.
} 
nia łącząca mnie jeszcze z nimi więź" ${ }^{4}$. Podejmując zagadnienie fenomenów samotności i wspólnotowości w odniesieniu do sylwetki rumuńskiego myśliciela, nie sposób nie odwołać się do jego biografii jako zasadniczej względem twórczości w celu pokazania tych dialektycznych rozgrywek. Fakty z życia Ciorana przywołać więc należy bezdyskusyjnie, zwłaszcza że zabieg ten zdecydowanie dopełni jego wizerunek, ukazując dorobek intelektualny w kontekście biograficznym. Zastrzegam jednakże, że ich przywoływanie nie będzie miało charakteru kompletnego i chronologicznego, jako że nie jest mą intencją usytuowanie się w roli biografa.

Emil Cioran, syn Elvirei i prawosławnego popa Emiliana, urodził się w 1911 roku w rumuńskiej wiosce Răşinari, w Karpatach. Nie był jedynym dzieckiem, w dzieciństwie towarzyszył mu brat Aurel i siostra Virginia, a jego z nimi relacje w dorosłym życiu skomplikowały się. Dojrzały już Emil wspomina ten okres z wielkim sentymentem, doceniając ów beztroski czas, który spędzał na pogawędkach z pasterzami, kontaktach z prostymi ludźmi wsi, przebywając nieustannie na łonie bujnej górskiej przyrody i ciesząc się jej walorami. W wieku lat pięciu przeżył pierwsze doświadczenie filozoficzne, jak sam je określił:

Mogę powiedzieć, że moje życie było zdominowane przez doświadczenie nudy. Poznałem ją już w dzieciństwie. Nie chodzi o nudę, którą można przezwyciężyć rozrywkami [...], ale o nudę można by powiedzieć, fundamentalna, polegającą na tym, że mniej lub bardziej raptownie, u siebie bądź u innych, albo w obliczu pięknego krajobrazu człowiek czuje, że wszystko jest puste, nie ma treści ani sensu. Pustka w sobie i na zewnątrz. Cały wszechświat rażony jest nicością.

To pierwsze doświadczenie egzystencjalne przez samego zainteresowanego datowane jest jako przełomowy moment $\mathrm{w}$ jego życiu, bo moment to przebudzenia jego ,ja”, wyswobodzenie się jego samego jako podmiotu, odłączenie od całości i wspólności istnienia ze światem, postawienie się naprzeciwko świata podmiotu wobec przedmiotu. To faktyczne zdanie sobie sprawy z własnej odrębności i konstatacja o swoim byciu samemu wobec świata, zrozumienie własnej samotności i samotności w ogóle jako fenomenu, który każda istota ludzka przeżywa osobiście, intymnie.

Cioran, ukończywszy gimnazjum, został przeniesiony przez swoich rodziców do rumuńskiego Sibiu, by tam pokonać kolejny szczebel edukacji. Był młodym, zdolnym chłopcem, którego pasją stała się literatura. Zaczął również sięgać po klasyków filozofii. Oprócz bardzo rozwiniętej samoświadomości, zainteresowania śmiercią (jako mały chłopiec zwykł rozmawiać z grabarzem, często spędzał czas na cmentarzu, zdarzyło się także, że bawił się ludzkimi szczątkami, o czym

${ }^{4}$ Tamże, s. 168.

${ }^{5}$ E. Cioran, Rozmowy z Cioranem, z Cioranem rozmawia Fernando Savater, thum. I. Kania, Warszawa 1999, s. 23. 
zaświadcza niemiecki biograf Ciorana, Bernd Mattheus w dziele Cioran. Porter radykalnego sceptyka), nie wyróżniał się niczym nadzwyczajnym, nie stronił też od kontaktów ze swoimi rówieśnikami. Dopiero w okresie podjętych w Bukareszcie studiów, kiedy oddał się głębokiemu namysłowi nad lekturami filozoficznymi, zaczął odczuwać pierwsze symptomy samotności wynikające przede wszystkim z bezsenności. Udręka insomnii noctis rozpoczęła się około 21. roku życia Ciorana, wtedy właśnie narodziło się pierwsze dzieło rumuńskiego myśliciela $\mathrm{Na}$ szczytach rozpaczy i było najprawdziwszym dziełem z trzewi, wołaniem cierpiącego, lirycznym uniesieniem pełnym szczerości i nieubogim w ufność i nadzieję, ale także wyrażającym głębokie rozczarowanie filozofią jako dyscypliną niedającą odpowiedzi. Książka ta powstała w znacznej mierze jako konsekwencja nocnych tortur, a w bezsenności nocy, jak zaświadcza sam jej autor, świat jawi się nam inaczej, wszystko spowite jest mrokiem, zatem i ludzkie myśli nie mogą grzeszyć jasnością. W rozmowie z Léo Gillet wyznaje o niemocy snu:

Jest to doświadczenie nadzwyczaj bolesne, katastrofa. Ale pozwala nam ono zrozumieć rzeczy, jakich inni nie mogą zrozumieć; bezsenność stawia nas poza obrębem wszystkich żyjących, na zewnątrz ludzkości. Jest się wykluczonym. [...] Czymże jest bezsenność? O ósmej rano jest pan dokładnie w tym samym punkcie co o ósmej wieczorem! Nie ma żadnego postępu. Jest tylko ta bezkresna noc. A życie możliwe jest tylko wskutek nieciągłości. Dlatego ludzie znoszą życie - na skutek nieciagłości, jaką zapewnia sen. [...] gdy pan czuwa, jest pan sam... z kim? Z nikim. Jest pan sam z myślą o Nicości ${ }^{6}$.

Walka Ciorana $\mathrm{z}$ bezsennością trwała niespełna siedem lat, nietrudno zatem wyobrazić sobie, jak tak długi okres bezsenności może „złamać” człowieka, ogołocić go z wszelkich pragnień, absolutyzując tym samym tylko jedno z nich snu zamiennie ze śmiercią jako jego substytutem. Cierpiący Cioran wyalienował się ze społeczności, w której był zanurzony, a był to czas studiów oraz pracy w gimnazjum, rozwinął mocno nocne życie, tułając się po domach publicznych i szukając ukojenia $\mathrm{w}$ ramionach prostytutek. Nie szukał pomocy, poszukiwał ukojenia w odosobnieniu, bliski był szaleństwu. O samotności z tamtego okresu dowiadujemy się, czytając jego pierwszą książkę, w której w jednym z rozdziałów opisuje samotność, dokonując jej rozróżnienia na dwa rodzaje:

Są dwa sposoby odczuwania samotności: gdy czujesz się sam na świecie i gdy odczuwasz osamotnienie świata. [...] Wrażenie, że jesteś wrzucony i zawieszony w świecie, niezdolny przystosować się do niego, zżerany od środka, niszczony przez własne słabości bądź uniesienia, nękany własnymi niedostatkami, obojętny na zewnętrzne odmiany świata, które mogą być pełne blasku albo mroczne, a ty i tak

\footnotetext{
${ }^{6}$ Tamże, Rozmowy z Cioranem, z Cioranem rozmawia Léo Gillet, dz. cyt., s. 72.
} 
trwasz wewnątrz swego duchowego dramatu - oto co oznacza samotność indywidualna. Odczuwanie samotności kosmicznej, choć zachodzi również w jednostce, ma źródło nie tyle w jej czysto subiektywnym zamęcie, ile raczej we wrażeniu, że ten świat jest porzucony, w doznaniu zewnętrznej nicości ${ }^{7}$.

Cioran odczuwał samotność na wspomniane przez siebie dwa sposoby, ta dwuaspektowość jej przeżywania widoczna jest na pokaźnej przestrzeni stron jego książek, ale zupełnie intuicyjnie sięgając po chociażby dwa jej tytuły: Zły demiurg czy $O$ niedogodności narodzin, czytelnik będzie w stanie rozpoznać te dwie samotności - indywidualną i kosmiczną. Z Cioranowskiej wizji człowieka wrzuconego w czas mimowolnie, w świat, którego stworzenie jawi się jako żart okrutnego i dowcipnego Boga, wyłania się samotność człowieka i samotność świata właśnie. Oto rumuński filozof nie tylko targany obsesją śmierci, ale i obsesją początku - narodzin, wyznaje w $O$ niedogodności ...: „Nie biegniemy ku śmierci, uciekamy przed katastrofą narodzin”, a następnie: „Obsesja narodzin, przenosząc mnie w czas poprzedzający moją przeszłość, sprawia, że przyszłość, teraźniejszość, a nawet i przeszłość tracą dla mnie urok" ny, to jest u pa de k w c z as (a jest to notabene tytul jednego z jego dzieł), postrzega Cioran jako początek swojej samotności, bo każdy byt jest konstytutywnie samotny, każde więc istnienie, gdy się pojawia, jest z gruntu samotne. „Życie ujawnia się dopiero przez odrębność - która jest zasadniczym fundamentem samotności - dlatego każdy jest samotny tylko $\mathrm{z}$ tego powodu, że jest jednostką" ${ }^{10}$ pisze w Zarysie rozkładu. Istota ludzka w momencie przyjścia na świat, wyodrębnia się z niego, choć zawiera się w nim. To akcydentalne, jedynie bowiem przypadkiem człowiek staje się bytem w świecie, wrzucenie w świat rozpoczyna partykularną ludzką historię, staje się punktem wyjścia ludzkiego losu i odmierzane jest w czasie. Człowiek zanurzony w świecie, który funkcjonuje w czasie i przestrzeni, jednocześnie podlega tym prawom, ale w swym podleganiu światu pozostaje zupełnie samotny i zupełnie odrębny od świata. „Narodziny i łańcuch to synonimy. Ujrzeć światło dnia to ujrzeć kajdanki [...]"11, a zatem przekleństwo narodzin to wyrok skazujący na samotność. Indywidualna samotność Cioranowska stanowi więc odpowiednik wyróżnionej w ramach refleksji monoseologicznej samotności ontologicznej, bo przecież tak samo w myśleniu Emila Ciorana, jak i w dyskursie filozofii samotności, jest to samotność, która konstytuuje byt ludzki, nadaje mu charakteru takiego bytu, jakim właśnie jest, znamionuje go tym samym w jego późniejszym trwaniu

${ }^{7}$ E. Cioran, Samotność indywidualna i samotność kosmiczna, w: tenże, Na szczytach rozpa$c z y$, thum. I. Kania, Warszawa 2007, s. 103.

${ }^{8}$ Tenże, O niedogodności narodzin, tłum. I. Kania, Kraków 1996, s. 4.

${ }^{9}$ Tamże, s. 9.

${ }^{10}$ E. Cioran, Zarys rozkładu, tłum. M. Kowalska, Warszawa 2006, s. 81.

${ }^{11}$ Tenże, O niedogodności narodzin, dz. cyt., s. 164. 
i jednocześnie współdecyduje o ambiwalencji ludzkich dążeń od „ja” do „my” i odwrotnie, i na zawsze.

Osobną kwestię stanowi wymieniona w Na szczytach rozpaczy samotność kosmiczna, która w ramach paradygmatu Ciorana koresponduje $\mathrm{z}$ jego stosunkiem do Boga oraz do zagadnień religijnych, a która na łamach rozważań monoseologicznych odsyła do nurtu kontemplatywnego samotności, gdzie ta ujmowana jest w kategoriach utylitarno-sapiencjalnych. Takie ujęcie samotności podstawową wartością czyni bycie sobą, które realizować można poprzez kontemplację, ta zaś w konsekwencji umożliwić może poznanie Boga. W przekonaniu Ciorana samotność kosmiczna zasadza się na osamotnieniu świata, porzuceniu go przez Boga, który jest jeszcze bardziej samotny niż dzieło swojej kreacji, choć jak twierdzi rumuński myśliciel: „Stworzenie świata nie ma innego wytłumaczenia oprócz lęku Boga przed samotnością. Mówiąc inaczej, rolą nas, stworzeń, jest nie co innego, tylko rozerwanie Stwórcy" ${ }^{12}$. Cioran nie rozumie istnienia takiego świata ze wszystkimi jego okrucieństwami, śmie zakładać, że dobry Bóg nie imałby się tak niewybrednych żartów, by zaserwować człowiekowi życie w cierpieniu, samotności ze świadomością własnej zgnilizny i jedyną ucieczką - w iluzję. Istnienie świata, w którym sam autor jest zanurzony, dowodzi jedynie tego, że jego stworzyciel musiał być raczej złym demiurgiem, aniżeli dobrym, miłosiernym Ojcem. Zastanawia się więc Cioran, czy i sam Stworzyciel z dużym poczuciem humoru nie jest ofiarą samotności właśnie.

Najprościej rzecz ujmując, myśl Ciorana jest następująca - Bóg stworzył świat, by zapełnić pustkę, by uchronić się przed samotnością, która i ten stworzony przezeń świat owładnęła, co więcej - dzieło stworzenia wcale nie wypełniło pustki, a zapewniło jedynie marną rozrywkę jego Stworzycielowi. W samym centrum stoi zaś człowiek, który jest samotny w sposób istotowy. Poszukuje w swej samotności drogi wyjścia, skłaniając się ku rozmowie, a w poszukiwaniu rozmówcy wymyśla Boga. „Gdy docieramy do końca wewnętrznego monologu, na krańce samotności, z braku innego rozmówcy wymyślamy Boga - doskonały pretekst do rozpoczęcia dialogu"13 czytamy w Zarysie rozktadu. W Świętych $i$ łzach, książce uznanej za najbardziej obrazoburczy wykwit Cioranowskich przemyśleń czytamy: „Pojawienie się Boga jest równoczesne z pierwszym dreszczem samotności. [...] Samotność bez Boga to najczystsze szaleństwo"14. Cioran w swym najintymniejszym wnętrzu poszukiwał jednak kogoś bliskiego, a jeśli jest z mej strony nadużyciem interpretacyjnym dodanie przymiotnika „bliski”, to z pewnością poszukiwał kogoś, kogokolwiek. Częste o Bogu wzmianki, na przemian przyzywanie Jego obecności i obelżywe określanie Go, to nic innego jak

\footnotetext{
${ }^{12}$ E. Cioran, Święci i łzy, thum. I. Kania, Warszawa 2003, s. 61.

${ }^{13}$ Tenże, Arogancja modlitwy, w: tenże, Zarys rozkładu, dz. cyt., s. 126.

${ }^{14}$ Tenże, Święci i lzy, dz. cyt., s. 36.
} 
dowód na Cioranowską potrzebę rozmowy, na dialogiczność istoty ludzkiej, która jakkolwiek długo może wytrwać w autozamknięciu, jednocześnie dąży do jakiegoś „my”. Wymyślanie obiektu, z którym się w wyobraźni rozmawia, nieustanne przywoływanie go w myślach zaświadcza o potrzebie wypełnienia pustki, choć sam Cioran afirmował ją i można by się pokusić o założenie, że dla niego powinno się ją pisać z dużej litery, to jednocześnie nazbyt pusta była ta pustka, by móc znosić jej ciężar, wypełniona Bogiem stała się paradoksalnie lżejsza. Dla uważnie śledzącego Cioranowskie ,wynurzenia” czytelnika może wydać się rumuński filozof osobą ocierającą się o szaleństwo, bo najpierw wymyśla Boga, gdy w swym monologu wewnętrznym dojdzie do krańców samotności, innym razem twierdzi, że świat stworzony został przez Boga po to, by stać się dla niego swoistym remedium na samotność. Nic bardziej mylnego, Cioran pragnie uchronić się przed szaleństwem własnej samotności, poszukuje rozmówcy do odwzorowania swoich lęków i utrapień, pragnie potwierdzenia siebie, a przecież niemożliwe jest to zrobić, pozostając jedynie z samym sobą. Walka Ciorana z Bogiem, jego potyczki ze świętymi, zatargi z religią w ogóle to doskonały obraz ścierania się dwóch dążeń: ku samotności i ku jakiemuś „my”, ku jakiejś wspólnotowości.

Dlaczego człowiek nie może trwać zamknięty w samym sobie? [...] Czy nie byłoby pożyteczniej zatonąć w nurcie wewnętrzności, nie myśląc zgoła o żadnej obiektywizacji, i smakować tylko z cichą rozkoszą najintymniejsze swoje porywy i poruszenia? [...] Powściąganie treści domagających się obiektywizacji, tamowanie energii dążących do eksplozji zawsze grozi poważnym niebezpieczeństwem, jako że może nadejść chwila, gdy nie da się już panować nad wzbierającą energią. Wówczas następuje załamanie, które jest wynikiem nadmiaru. Są przeżycia i obsesje, z którymi nie sposób dalej żyć. Czyż ratunkiem nie jest wtedy wyznanie ich? ${ }^{15}$

zapytuje Cioran, otwierając swój literacki debiut. Już sam bogaty dorobek jego życia zaświadcza o potrzebie obiektywizacji wszelkich stanów, które Cioran przeżywał. Nie mogło to się odbyć w mroku własnych myśli. Rumuński myśliciel sam swoje pisarstwo określa sposobem na przetrwanie, odroczeniem samobójstwa, dystansowaniem się do siebie samego. Zapytany w jednym z wywiadów, dla kogo pisał i pisze książki, odpowiedział, że choć zabrzmi jak hipokryta, to dla nikogo, dla siebie samego. Cioranowskie pisanie to romans wewnętrznego z zewnętrznym, publikowanie jeszcze bardziej ów romans uwiarygodnia, czyni go oficjalnym. Gdy wewnętrzne wychodzi ku zewnętrznemu, to samotność przestaje już dalej chcieć być sama ze sobą, dąży ku czemuś poza swoimi granicami. W wywiadzie z Jean-François Duvalem zapytany: „po co pisać?”, odpowiada:

\footnotetext{
${ }^{15}$ E. Cioran, Być lirycznym, w: tenże, Na szczytach rozpaczy, dz. cyt., s. 5.
} 
Teoretycznie jednak nie powinienem napisać ani opublikować ani słowa. Gdybym był absolutnie wierny sobie samemu. Ale nie mogę być wierny, ponieważ musiałem stanąć na własnych nogach, jakoś przystosować się do życia. Musiałem wdać się w tego rodzaju kompromis i handel, żeby w ogóle żyć. Jestem absolutnie przekonany, że gdybym nie pisał, popełniłbym samobójstwo. Jestem tego absolutnie pewien ${ }^{16}$.

Zapytany dalej o dużą częstotliwość użycia zaimka „my” konstatuje następująco:

Mówiąc „my” często myślę ,ja”. Nie jest to z pewnością „my” człowieka politycznego, „my” proroka czy też nie wiadomo kogo, kto przemawia w imieniu innych. To z pewnością nie tłum ani żadna inna zbiorowość. Nigdy nie mówiłem w niczyim imieniu. Chodziło mi tylko o uniknięcie ,ja”, które w pewnych sytuacjach nie jest możliwe, i o nadanie wyglądu obiektywnego temu, co moje, subiektywne ${ }^{17}$.

Potrzeba obiektywizacji to potrzeba wyjścia z granic samego siebie ku innemu, to potrzeba nawiązania relacji. Cioran piszący i publikujący takie relacje z czytelnikiem w sposób pośredni nawiązuje, choć z samej zasady działają one w jednym kierunku, to są wyciagnięciem ręki jednego ku wielu.

Obraz Ciorana jako człowieka samotnego wyłania się przede wszystkim z zapisanych wewnętrznymi udrękami stron jego książek, które same już z faktu swego zaistnienia stanowią rozgrywkę ich autora z bliżej nieokreśloną wspólnotowością. Przyjrzawszy się jednak jego prywatnemu życiu, można odnieść zgoła przeciwne wrażenie. Jak wyżej wspomniałam, młody Emil to może nazbyt świadomy, a przez to i zanadto wrażliwy chłopak, któremu szczególnie bliska jest refleksja nad śmiercią, ale nie odbija się to w żaden sposób na jego relacjach z rówieśnikami. Niewątpliwym okresem osamotnienia można określić ten czas, w którym cierpiał na bezsenność, w wyniku której na mocy własnej decyzji alienował się z otaczającej go społeczności. Cioran w odsłonie dojrzałego mężczyzny to zupełnie inna historia, choć nierzadko określany był jako samotnik z paryskiej mansardy (mając na myśli francuski okres jego życia, ten najbardziej dojrzały). Rumuński myśliciel nie stronił od ludzi, wręcz przeciwnie - spotykał się często ze znanymi literatami, wydawcami, uczestnicząc żywo w kulturalnym życiu Paryża. Doskonale zdawał sobie sprawę, że trudne są warunki utrzymania się na powierzchni sławy i nie jest mitem konieczność wydawania jednej książki rocznie jako gwarantu podtrzymania literackiego istnienia, stąd też umiejętnie zabiegał o względy ważnych osobistości. Jego poszukiwanie kontaktu z ludźmi wiązało się także z potrzebą bycia finansowanym; gdy nie był w stanie się utrzymać z wynagrodzenia płynącego ze sprzedaży książek, wnet znajdował jakiegoś opiekuna, który widział w nim potencjał. $Z$ wymienionej już pozycji biograficz-

\footnotetext{
${ }^{16}$ Tenże, Rozmowy z Cioranem, z Cioranem rozmawia Jean-François Duval, dz. cyt., s. 41.

17 Tamże.
} 
nej Bernda Mattheusa można dowiedzieć się o wielu takich sytuacjach, w których Cioran z myślą o przeżyciu, stawał się czyimś utrzymankiem tudzież „kombinował" (jak sam to określa) z przedłużaniem naukowego stypendium na poczet pisania doktoratu, którego ostatecznie nie ukończył. Cioran nie był też samotny pod względem bycia w związku z kobieta, dzielił swoje życie z nauczycielką języka angielskiego, Simone Boué, która troszczyła się o przyziemne sprawy w ich związku, zapewniała rumuńskiemu filozofowi spokój materialny. Niemiecki pisarz, Mattheus w Prologu do biografii Ciorana opisuje wizytę w paryskim mieszkanku Ciorana nr 21 przy Rue de l'Odéon; oto fragment tegoż opisu: „W «salonie» dało się wyczuć obecność kogoś jeszcze. Od czasu do czasu Cioran odsuwał przesuwne drzwi, rzucał kilka gwałtownych słów, po czym wracał do stolika ze słonymi paluszkami i ozdobnymi butelkami z alkoholem. [...] Cioran ani słowem nie wspomniał o swej towarzyszce życia, Simone Boué, tak jakby kobieta psuła obraz samotnika" ${ }^{18}$. Z przekazu ustnego znakomitego polskiego thumacza dzieł Ciorana, Ireneusza Kani wynika, że Cioran bardzo dbał o swój wizerunek myśliciela samotnego, marginalnego, odrzuconego, w rzeczywistości zaś wiódł on względnie spokojne i ustabilizowane życie u boku Simone, która była silnym ramieniem w ich związku. Filozof nie czuł się w tej relacji samotny, doskonale się rozumieli, łączyły ich wspólne inspiracje literackie, żyli ze sobą aż do śmierci Emila ${ }^{19}$. Codzienna egzystencja rumuńskiego aforysty nie przypominała w niczym żywota samotnika, człowieka wyalienowanego, żyjącego na skraju decyzji o ostatecznej autodestrukcji. Jednakże po śmierci Ciorana Simone odnalazła Zeszyty, wcześniej nie miała pojęcia o ich istnieniu. W swym liście do Kani z 15 sierpnia 1995 roku pisze o tym niezwykle interesującym znalezisku i nie ukrywa swojego głębokiego zdziwienia jego zawartością, przyznaje, że są kontrowersyjne i nie spodziewała się, by ktoś, z kim tyle czasu dzieliła swoje życie i z kim była tak blisko, mógł się okazać tak wielkim nieznajomym. Treść Cioranowskich diariuszy może bowiem szokować, zwłaszcza że wyłania się $\mathrm{z}$ nich nierzadko obraz człowieka zdruzgotanego, niewidzącego nigdzie sensu, pozbawionego nadziei. Mimo iż Simone znała jego dzieła, Zeszyty wielce ją zdumiały, bo Cioran je przed nią ukrywał. Pytanie, jakie się nasuwało, dotyczyło sensu tegoż kamuflażu, bo skoro w swej stylistyce oraz pod względem nagromadzenia rozmaitych inwektyw były podobne do tych dzieł, które publikował, dlaczego uchroniły się od pokusy uwolnienia od własnych obsesji? Cioran był bardzo konsekwentny w budowaniu swojego wizerunku samotnika, unikał wywiadów, udzielił ich niewiele, gdy już pozował do zdjęcia, starał się nie zdradzać się

${ }^{18}$ B. Mattheus, Cioran. Portret radykalnego sceptyka, thum. R. Reszke, Warszawa 2008, s. 17.

${ }^{19}$ Wystapienie Ireneusza Kani w Instytucie Filozofii Uniwersytetu Opolskiego w ramach konferencji „Cioran - W pułapce istnienia”, Opole, 4. X. 2011 r. Temat wystąpienia - Korespondencja z Simone Boué. I. Kania na bieżąco tłumaczył z języka francuskiego swoją korespondencję z partnerką Ciorana, gdy ten przebywał w szpitalu. Listy te obejmują lata 1993-1995. 
uśmiechem. „Cioran śmiał się chętnie i często, choć dbał o to, by nie publikowano fotografii przedstawiających go jako człowieka pogodnego i zrelaksowanego" ${ }^{\text {"20 }}$ pisze Bernd Mattheus. Z przekazu ustnego I. Kani wynika również, że Cioran był doskonałym partnerem do rozmów, potrafił słuchać i wykazywać zrozumienie. $\mathrm{Z}$ tego powodu często był zapraszany na obiady jako towarzysz intelektualny, wzorcowy rozmówca, który uprzyjemni czas i uszlachetni go cnotą erudycji.

Życie i twórczość Ciorana, jako całokształt stanowiący pole jego dążeń ku samotności oraz ku wspólnotowości, stały się dla mnie inspirujące przede wszystkim ze względu na charakterystyczną ideę samobójstwa. Jest ona punktem początkowym, naprowadzającym mnie na tropy dyskursu samotności, jaki można rozpoznać w zawartości treściowej Cioranowskich dzieł. Wizytówka rumuńskiego filozofa, czyli sławetne i brzemienne w znaczenie wyznanie: „Żyję tylko dlatego, że jest w mojej mocy umrzeć, kiedy tylko mi się spodoba: bez idei samobójstwa zabiłbym się już dawno"21, to definicja najpełniej oddająca sens idei samobójstwa. Możliwość popełnienia aktu ostatecznej autodestrukcji stanowiła dla Ciorana potęgę, możliwość stanowiła dlań wyższy stopień modalności aniżeli istnienie, realność. W każdej potencjalności widział więcej siły niż w realnym, ponieważ potencjalność to wolność. Człowiek Cioranowski to istota wolna w znaczeniu wolności „do”, zdeterminowana w swej wolności „od”. Człowiek jako istota wolna i suwerenna nie podlega żadnym moralnym nakazom, żadnemu wyższemu bóstwu, jest jedynym depozytariuszem swojego istnienia, a ponieważ istnieje wbrew swej woli, a przynajmniej pomimo niej, nie podjęła sama decyzji o zanurzeniu w realny świat, nie jest zobligowana żadną umową, by w nim pozostać. Możliwość popełnienia samobójstwa to często jedyne pocieszenie, jakie człowiek może znaleźć, w związku z tym i jedyna jego siła, ,,deska ratunkowa”. Cioranowska idea samobójstwa przemyca ze sobą wcześniejsze założenie, mianowicie założenie wolności. W dyskursie monoseologicznym wolność w powiązaniu z fenomenem samotności nabiera charakteru myśli przewodniej, sytuując się w narracji indywidualistycznej. Wolność, która jest podstawą możliwości samotności, jest zaledwie zwiastunem pełni wolności, do której prowadzi samotność. Akt wolności i samotności wzajemnie się przenikają, stanowiąc względem siebie implikację obustronna, tym samym bardzo utrudniając analizę obu fenomenów jako wzajemnie powiązanych. Czy Cioran w wyniku samotności wpadł na pomysł myślenia o samobójstwie wyzwoleńczo i wolnościowo? Czy wyrażając akt swojej wolności poprzez ideę samobójstwa wtórnie wywołał samotność? Samotność jako diagnoza stanu psychicznego twórcy idei samobójstwa wynika też nie przede wszystkim z jego wolności, rozumianej jako niezależność

${ }^{20}$ B. Mattheus, Cioran ..., dz. cyt., s. 16.

${ }^{21}$ E. Cioran, Aforyzmy, tłum. J. Ugniewska, Warszawa 1993, s. 25. 
(szczytowy punkt samotności), ale wiąże się z samym myśleniem o śmierci. W dyskursie psychologicznym fenomen samotności łączy się grubą linią zależności z aktem ostatecznej autodestrukcji. Jak pisze Brunon Hołysz, wybitny polski przedstawiciel suicydologii: „Zdaniem wielu badaczy samotność można uznać za jeden z podstawowych czynników prowadzących do różnych chorób organizmu, psychopatologii, zjawisk patologii społecznej, [...], a także do zamachów samobójczych"22. Samotność może stać się główną przyczyną zamachu na swoje życie, ale czyż samobójstwo skonceptualizowane w postaci idei nadal stanowi wyraz samotności? A gdyby spojrzeć na nie jak na wyciągniętą ku wspólnocie rękę? Idea, która mnie ocala, pozwala mi być pośród innych, daje mi możliwość dążenia ku „my”, nawet jeśli pozostanie to jedynie w sferze potencjalności, to stanowi ,aż” w kierunku wspólnoty.

W Sylogizmach goryczy odnajdujemy rozdział zatytułowany Cyrk samotności. Jak pozostałe rozdziały tej książki stanowi on zbiór aforyzmów uporządkowanych pod kątem tytułowego tematu. Już samo zestawienie wyrazów „cyrk” i „samotnośś” wydaje się, jeśli nie intuicyjnie sprzeczne, to przynajmniej intrygujące. Jak bowiem widowiskową sztukę, w której jej główni bohaterowie eksponują umiejętności, odwagę oraz harmonię, przystawić do fenomenu samotności? Cioran jednakże dokonuje takiego zestawienia i za pomocą aforystycznych perełek folguje swoim bolączkom, najczęściej przywołując śmierć, Boga, zbiorowisko ludzkie i wszelakie resentymenty względem samego siebie. Pisze mianowicie: „W kontakcie z ludźmi zatraciłem całą świeżość swoich newroz” ${ }^{23}$ albo „Pozbyłem się Boga z potrzeby skupienia; uwolniłem się od ostatniego natręta” ${ }^{24}$ lub też „Dlaczego się wycofywać i opuszczać grę, skoro tylu mamy jeszcze ludzi do oszukania?"25. Cały rozdział naszpikowany jest niejako sprawozdaniem ze swoich relacji z samym sobą, z innymi, z Bogiem, stanowiąc tym samym ,samorozliczenie". Bóg, który wcześniej, jak sam Cioran przyznał, potrzebny był do dialogu, gdy nieznośna była samotność, tym razem okazuje się intruzem jego myśli, niepozwalającym mu na bycie sobą, ludzie, którzy go otaczają mimowolnie, odbierają mu jednocześnie jego prawdziwe ,ja”, a równocześnie cynicznie kalkuluje, że gra we wspólnotowość jest szalenie interesująca, bo zawsze znajdzie się ktoś, kogo warto oszukać. Można odnieść wrażenie, że rumuński myśliciel zapomniał o dotychczasowej linii budowania wizerunku samotnika lub też świadomie z niego zrezygnował, pogrywając sobie ze swoim czytelnikiem.

Pryzmat samotności, przez który pozwoliłam sobie spojrzeć na sylwetkę rumuńskiego skandalisty, okazuje się, nie jest jedyną perspektywą, bo oto mamy

${ }^{22}$ B. Hołyst, Suicydogenne aspekty samotności, w: tenże, Zrozumieć samotność..., dz. cyt., s. 277.

${ }^{23}$ E. Cioran, Cyrk samotności, w: tenże, Sylogizmy goryczy, dz. cyt., s. 89.

${ }^{24}$ Tamże, s. 92.

${ }^{25}$ Tamże, s. 93. 
też spojrzenie „my”, czyli Ciorana uwikłanego w relacje międzyludzkie, i choć wyraźnie widać jego mariaż z samotnością, to zauważyć też nietrudno przejawy jego zainteresowania relacjami z innym, drugim - wspólnotą. Oba fenomeny, mimo iż nie grają roli pierwszoplanowej ani w ramach zapisanych przez Ciorana stronic, ani w historii jego życia, to wciąż utrzymują swoją relewantność. Warto jest zatem mieć je na względzie zarówno w refleksji nad Cioranowską myślą jak i w dyskursie dialektyki samotności i wspólnotowości. Cioranowskie zaprzysiężenie $\mathrm{z}$ samotnością, które odbywa się $\mathrm{w}$ formie zmaterializowanej pismem, nie zostaje przedłużone na prywatne życie - w tym już dochodzi do nieustannego flirtu z innym, z innymi, z bliżej nieokreślonym „my”. Należy także zaznaczyć, że flirt ten bocznymi ścieżkami przenosi się na jego twórczość, w której przecież wprawne czytelnicze oko dostrzeże nieraz wyrazy tęsknoty za czymś poza ,ja”. Cioran zdawał sobie sprawę z zagrożenia, jakie niesie ze sobą wdanie się w kontakty $\mathrm{z}$ ludźmi, wstąpienie $\mathrm{w}$ unię $\mathrm{z}$ innymi to pozbawienie się swej wielkości i jedyności, zgoda na przystosowanie. Gombrowiczowskie „Międzyludzkie” to niebezpieczeństwo większe od własnej samotności: „Wygnaj ludzi z twych myśli, niech nic zewnętrznego nie kala twej samotności, błaznom pozostaw troskę o szukanie podobnych im. Inny cię umniejsza, bo zmusza cię do odgrywania jakiejś roli [...]"26. Cioranowskie zmagania z samym sobą i z umiejscowieniem siebie w relacjach z innymi to doskonały przykład dialektyki dążeń ku samotności i ciagot społecznościowych. A skoro: „Samotność nie uczy, jak być samym, lecz jak być jedynym"27, to pozostając we wspólnocie, człowiek może zachować swoje prawo do samotności, obronić najintymniejszą przestrzeń dla swojej sobości, a jednocześnie w swej wyedukowanej przez samotność jedyności pozostaje mu możliwość zwrócenia się ku wspólnocie. Dialektyka ku ,ja” oraz ku „my” trwa nieustająco, przenoszą się jedynie akcenty, a Cioranowskie zestawienie „życie - twórczość" bardzo trafnie owe akcenty uwidacznia.

\section{BIBLIOGRAFIA}

Cioran E., U źródet pustki, w: tenże, Sylogizmy goryczy, tłum. I. Kania, Wydawnictwo Aletheia, Warszawa 2009, s. 161-180.

Cioran E., Cyrk samotności, w: tenże, Sylogizmy goryczy, thum. I. Kania, Wydawnictwo Aletheia, Warszawa 2009, s. 85-110.

Cioran E., Samotność indywidualna i samotność kosmiczna, w: tenże, Na szczytach rozpaczy, tłum. I. Kania, Wydawnictwo Aletheia, Warszawa 2007, s. 103-105.

Cioran E., Zarys rozkładu, tłum. M. Kowalska, Wydawnictwo KR, Warszawa 2006.

\footnotetext{
${ }^{26}$ E. Cioran, Zeszyty 1957-1972, thum. I. Kania, Warszawa 2004, s. 345.
}

${ }^{27}$ Tenże, Zmierzch myśli, thum. A. Dwulit, Warszawa 2004, s. 5. 
Cioran E., Zmierzch myśli, tłum. A. Dwulit, Wydawnictwo KR, Warszawa 2004.

Cioran E., Zeszyty 1957-1972, thum. I. Kania, Wydawnictwo KR, Warszawa 2004.

Cioran E., Święci i łzy, thum. I. Kania, Wydawnictwo KR, Warszawa 2003.

Cioran E., Rozmowy z Cioranem, z Cioranem rozmawia Fernando Savater, thum. I. Kania, Wydawnictwo KR, Warszawa 1999, s. 13-24.

Cioran E., Rozmowy z Cioranem, z Cioranem rozmawia Léo Gillet, thum. I. Kania, Wydawnictwo KR, Warszawa 1999, s. 51-82.

Cioran E., Rozmowy z Cioranem, z Cioranem rozmawia Jean-François Duval, thum. I. Kania, Wydawnictwo KR, Warszawa 1999, s. 33-49.

Cioran E., O niedogodności narodzin, thum. I. Kania, Wydawnictwo Oficyna Literacka, Kraków 1996.

Cioran E., Aforyzmy, thum. J. Ugniewska, Wydawnictwo Czytelnik, Warszawa 1993.

Cioran E., Arogancja modlitwy, w: tenże, Zarys rozkladu, tłum. M. Kowalska, Wydawnictwo KR, Warszawa 2006, s. 126-128.

Cioran E., Być lirycznym, w: tenże, Na szczytach rozpaczy, tłum. I. Kania, Wydawnictwo Aletheia, Warszawa 2007, s. 5-10.

Hołyst B., Suicydogenne aspekty samotności, w: Zrozumieć samotność: studium interdyscyplinarne, red. P. Domeracki, W. Tyburski, Wydawnictwo Uniwersytetu Mikołaja Kopernika, Toruń 2006, s. 277-291.

Mattheus B., Cioran. Portret radykalnego sceptyka, thum. R. Reszke, Wydawnictwo KR, Warszawa 2008.

\section{SUMMARY}

This essay constitutes an attempt of showing the dialectics of the phenomenons of solitude and community on the example of Romanian writer and philosopher, Emil Cioran's works and life. The aim of this paper is to present the combination of Cioran's writings and his private life in comparison with the game in which solitude and community plays the main roles. The complete profile of Cioran greatly references to a philosophical subdiscipline, monoseology which treats on the phenomenon of solitude with its all complexity. The writings of Emil Cioran is a mutual interweaving of loner's striving for any community.

\section{Keywords}

solitude, community, dialectics, God, death, suicide notion, "myself", "we", suffering, Interpersonal, game

\section{Słowa kluczowe}

samotność, wspólnotowość, dialektyka, Bóg, śmierć, idea samobójstwa, ,ja”, „my”, wspólnota, cierpienie, Międzyludzkie, gra 